\title{
The Function of Parents Council and the Represantation of Parents Interests by this Council
}

\author{
Nazyktere Hasani \\ PhD candidate at EuropeanUniversity of Tirana; nhasani14@hotmail.com
}

Doi:10.5901/ajis.2015.v4n3s1p640

\begin{abstract}
This paper discusses the function of the parents council in high schools and the representation of the interests of parents by this council based on prejudices of students parents and members of the Council. The research question of this study was: "How functional is the parent council in high schools of the town of Gjilan?" For this research survey techniques are used, which were realized in the form of the questionnaire, a questionnaire for parents council members and a questionnaire for parents of the classes. Analysis of data obtained from this research indicates that parents' councils do not function at all that, they only exist formally. Parents thought that their interests are not represented enough by their representatives, and that no representative of them in the parents council has not ever contacted them to discuss the role, duties of the council, and get thoughts, suggestions or proposals on important issues dealing with work and school life of their children. Even members of the school council of parents emphasize that parents council in the school does not function properly because only once per year they have had meeting at the beginning of the school year, where the selection of their representatives for the school council is made. However, they say that all issues of particular interest to parents and students are treated by these representatives.
\end{abstract}

Keywords: scools, parents council, attitudes, parents, members of parents council

\section{Introduction}

The function of School Parent Council is an important issue for the school, parents, students, teachers when we consider the area of school-family partnerships. It is known that the Parents' Council is an internal authority of the school through which interests of participants in school life are represented and protected, helping progress and intellectual development of students and increase of the learning quality. Therefore the functioning of this council independently will be important for all participants of school life, especially for progress of cooperation and resolution of issues that are vital to students. With the operation of this council the interests of parents, students and teachers will be represented in the particular way, also will increase confidence, parents interest to actively participate in the school work and life."Parental involvement initiated by the school means the active role of the school in general pursuit of parents information about school policies, procedures and progress of their children, as well the incentive of parents to get involved in school councils and parents organizations" (Milosevic \&Malinic,2007, pg.150). Therefore, the Council of parents must be active in order for parents to be closer to the problems of school life of their children."The closer child's education the parent stands, the greater will be the impact on development and educational achievements of the child."(Fullan,2001, pg.294). This paper explicates the functioning of the Council of Parents in secondary schools based on the views of members of this council and parents of students who represent these members. The data gained offer us a real insight on the functioning of the council, possibly would even in the incentive and motivation of the school leaders and leadership of this council to make the council function.

\section{Methodological Organization of the research}

\subsection{Purpose of the research}

The purpose of this research was to present the real situation of parents' council function in high schools, from the prejudices of students' parents and members of this council. 


\subsection{Research questions of the survey}

Research question of this survey was: How functional is the Parent Council in high schools of the city Gjilan?

\subsection{Methodology of the research}

\subsubsection{Participant of the research}

This study is applied in three high schools of Gjilan, where the attitude of students' parents and members of the council of researched schools are reflected. In the research participated in total 90 parents, among them 45 members of the parent council of schools and 45 parents of the students, whose class are represented by these members.

\subsubsection{Used techniques}

Used technique of the research was the survey realized by the questionnaires for students' parents and for members of the council of parents. In the questionnaires are included total 24 questions, of closed and opened questions. The questionnaire questions have been compiled based on the manual for work of parents' council of primary and secondary schools. ${ }^{1}$

\section{Analysis and Data of the Research}

We're not presenting the analysis of all the data from questionnaires due to insufficient space, but only analysis of the data obtained from some questions of the questionnaire to members of the School Parent Council, and some questions for parents. Analysis of the data obtained from this research indicates that parents' councils do not work at all, they exist only on paper. Represented in the followings:

\subsection{Analysis of the data obtained from the questionnaire for members of Schools Parent Council}

In the question: How much are you informed, as a member of the Council, about your role, duties and responsibilities in this council?

\section{Graphic 2.1.1}

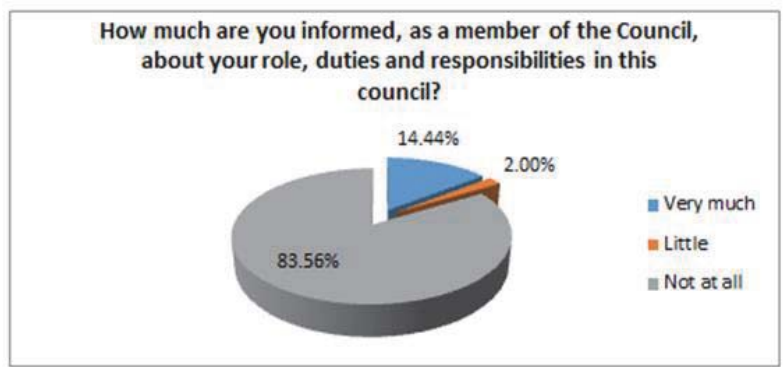

From the chart 2.1.1 we note that the majority of the Parent Council members participating in the survey $83.56 \%$ of them were for the alternative not at all, which means that have not been informed as members of the Council on the role, duties and responsibilities they have in this council. For alternative"little" $2 \%$, while for the alternative "very much" were $14.14 \%$ of them.

In the question: Does the Parent Council possess special place for holding activities? 


\section{Graphic 2.1.2}

Does the Parent Council possess special place for holding

activities?

0

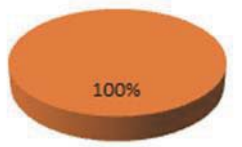

m Possess

in Doesn't possess

By analysing data from the graphic 2.1 .2 we note that $100 \%$ of the members of the school's Parent Council state that the parent council does not possess space for holding activities. The establishment of a special space for holding activities of Parents Council would enable a greater commitment for leadership and its members, especially the involvement of parents in school life of their children and as an equal partner of the school.

In the question: Did you attend regularly meetings of School Parent Council?

\section{Graphic 2.1.3}

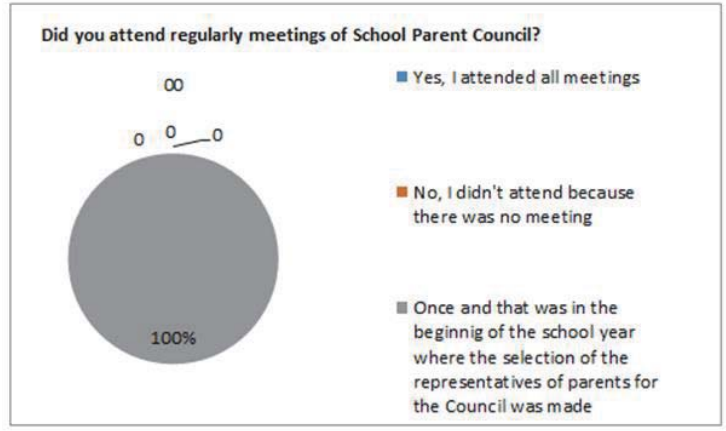

Based on the data in graphic 2.1.3 we note that $100 \%$ of them stated that they attended once during the year in the meeting of the Parents Council of the school, which means that the school Parent Council does not function properly.

In the other question: Do you consider the concerns, opinions and proposals of parents and do you present these in the Parent Council, we received the following answers:

\section{Graphic 2.1.4}

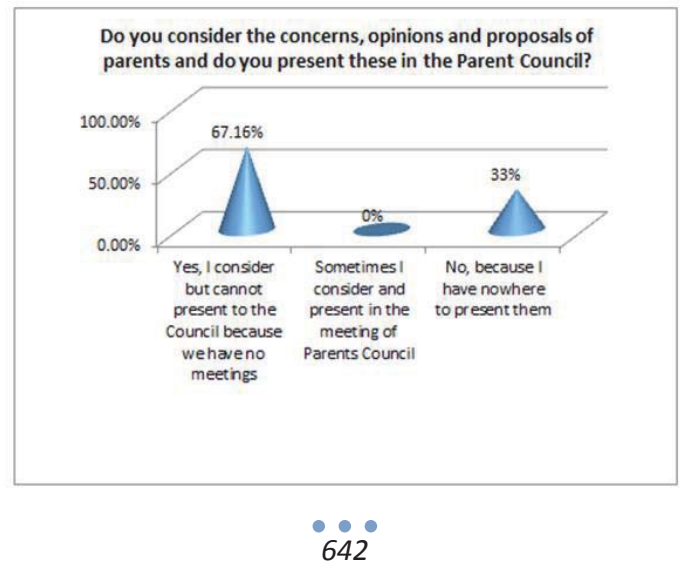


67.16\% of members of Parent Council participated in the survey of said that they consider the opinions, concerns and suggestions of parents, but do not present them in School Parent Council because of no meetings, while 33\% were for the alternative "not", because they don't have where to present them.

In the question: Do you ever talk during meetings with parents about problems that concern them?

\section{Graphic 2.1.5}

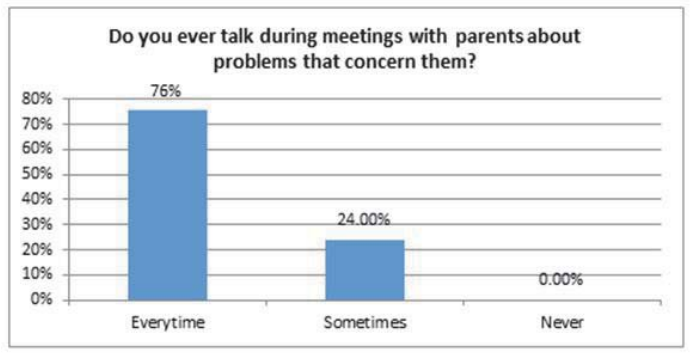

Analysing the data in graph 2.1 .5 we conclude that the majority of them, $76 \%$ said they always talk with parents about problems they have, while $24 \%$ of them said that sometimes.

In the question: Do the representatives to the School Council inform the Council about the content of the meetings and decisions of this council?

\section{Graphic 2.1.6}

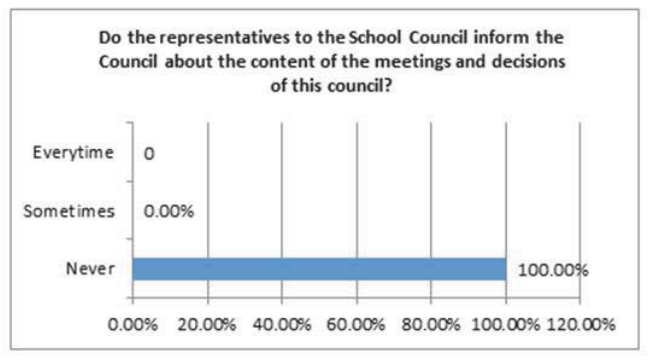

The data from Graph 2.1.6 shows that all members,100\% of them said that their representatives in the School Council did not inform them about the School Council meetings, which shows that these representatives are not required by the Council of parents to report about the meetings and decisions taken in the School Council.

In the following question: Have you ever discussed with other members of the Parent Council to organize any activity where other parents will be included?

\section{Graphic 2.1.7}

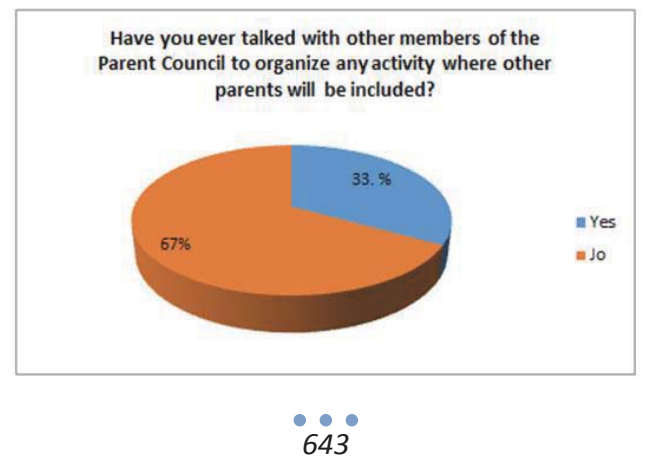


From the graphic 2.1.7 results show that $67 \%$ of them have not discussed with other members of this council for organizing any activity, justifying that as a member they cannot organize without the support of governing authority of the school. While $33 \%$ of them said that they have discussed with other members of this council to organize activities where other parents would be included.

In the question: Do you think that your representatives on the School Council fully treat the interests of parents and students?

\section{Graphic. 2.1.8}

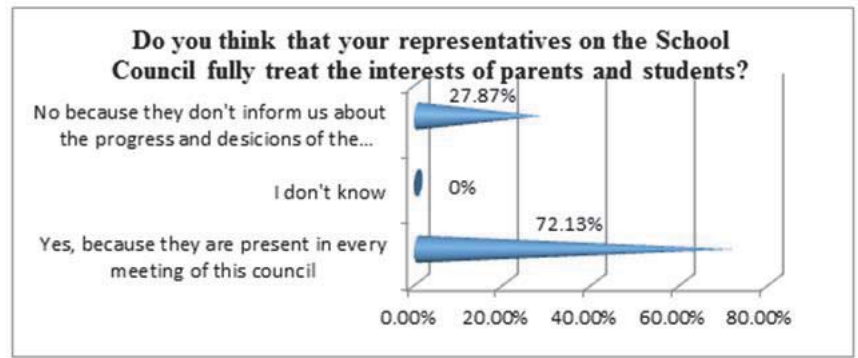

The data of analysis of the graph 2.1 .8 shows that $72.13 \%$ of the members participating in the survey think that their representatives in the School Council fully treat the interests of parents and students, while $27.87 \%$ state that they do not inform them about the progress and decisions of the meeting.

3.2 Analysis of the data obtained from the questionnaire for parents who are not members of the School Parent Council.

In the question for parents: Do you think that students and your interests are worthily represented by your representatives in the Parent Council of the School?

\section{Graphic 2.2.1}

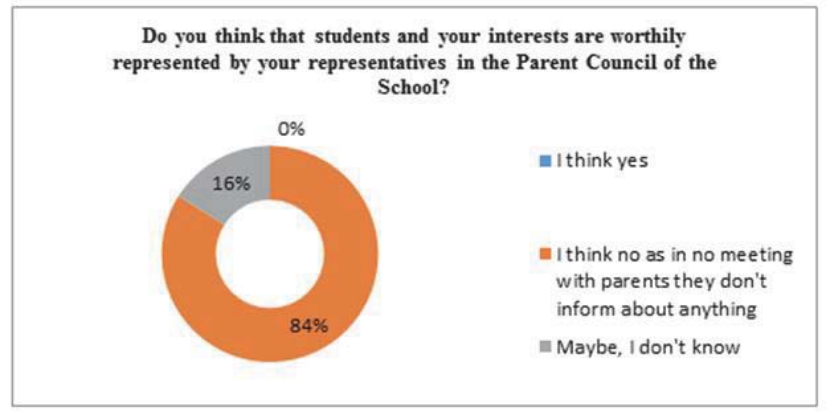

From the graphic 3.2 .1 of parental responses we notice that $84 \%$ of parents said that their interests are not worthy represented by their representatives, since in any meeting with the parents they do not inform them about anything, while $16 \%$ of parents were for alternative "maybe, I don't know".

Do your representatives in the Council of Parents ever discuss during meetings with parents for problems that have to do with work and school life of your children? 


\section{Graphic. 2.2.2}

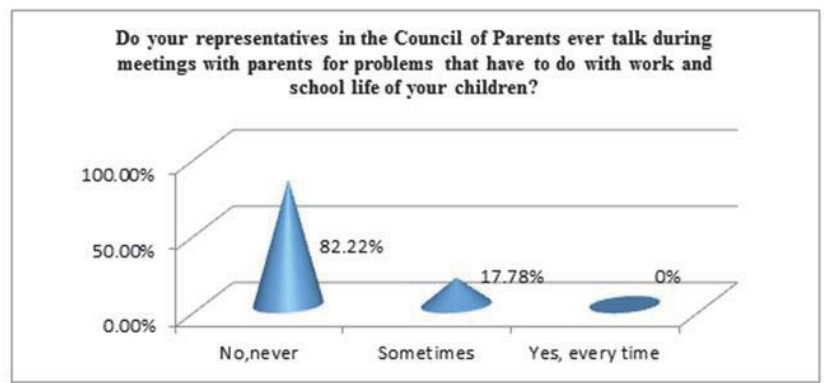

From the data of graphic 3.2.2 we can say that the majority of surveyed parents, $82.22 \%$ of them said that their representatives never talk with them, while $17.78 \%$ think that they sometimes talk with them.

Question: Do you agree with the opinion of the Parent Council members that all issues of your and students interest are fully handled by the parent representatives on the School Council?

\section{Graphic 2.2.3}

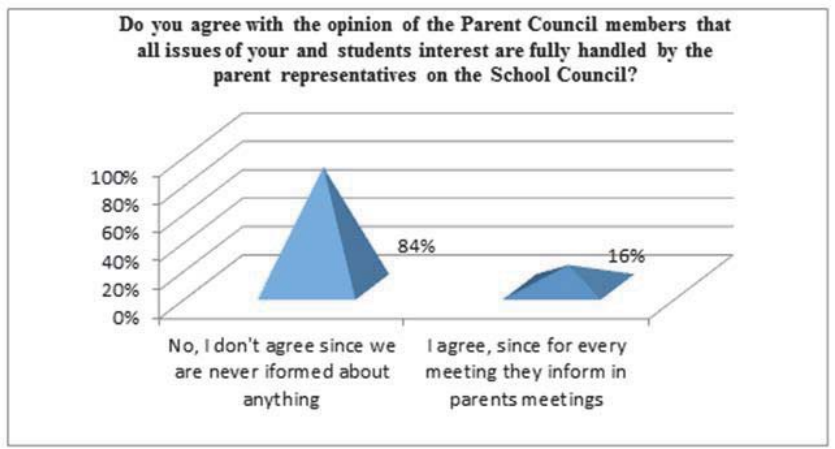

From the results presented in graphic 3.2 .3 we see that $84 \%$ of parents do not agree with opinions of the members that they representatives in the School Council treat fully they interests, since parents are never informed by them about the progress and decisions of this council, while $16 \%$ of parents agree, since for every meeting they inform in the parents meetings.

Following question: Do your representatives in the School Council ever inform you about the progress of the meetings of this council?

\section{Graphic 2.2.4}

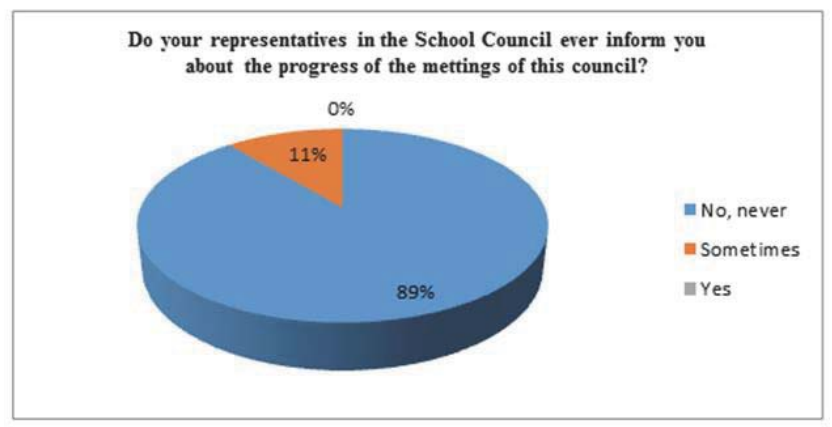


From the data of the graphic 3.2.4 we see that we have an approximation of the results with the previous question. Majority of parents, $89 \%$ of them said that their representatives never inform them about the progress of meetings of this council. While $11 \%$ said that they sometimes get informed.

In the question: Have your representatives ever invited you to take part in any activity organized by them?

\section{Graphic 2.2. 5}

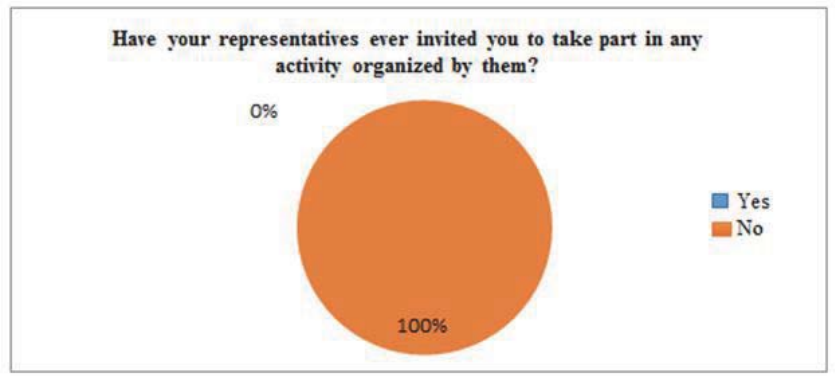

From the data of this graphic we note that $100 \%$ of parents say that they have never been invited to take part in any activity organized by them. From this we notice that their representatives have not organized any activity that would include parents.

\section{Data, Conclusion and Recommendations}

When talking about the functioning of this council, I think we have stagnation in this direction, because we are not inclined to work together, lacks of culture of cooperation and educational institutions are not paying much attention to the functioning of this council, knowing that the functioning of this council will increase parental involvement toward resolving problems students face. The data show dysfunction of the Parent Council and a not worthy representation of their interests. Parents thought that their interests are not represented enough by their representatives, and that no representative in parents' council has ever contacted them to discuss the role, duties of the council, and get thoughts, suggestions or proposals on important issues dealing with the work and school life of their children. Even members of the school parents' council emphasize that parents council in the school does not function properly because only once per year they have met, and that was at the beginning of the school year, when also was the selection of their representatives to the school council. However, they say that all issues of particular interest to parents and students are treated by these representatives.

On the other hand analysing the responses of parents, they say that their representatives in school councils do not ever contact with them and do not inform them about the progress and decisions of the council meetings. Therefore, it is needed:

- To engage high school leaders to make the Parent Council function.

- Parent representatives to be informed on time in the Parents Council and School Council about the role, duties and responsibilities that they will have as representatives in these authorities.

- Cooperation of all Parent Councils together across schools and make visits to schools of other countries to share experiences and different ideas so that these experiences can be applied in our schools.

- Representatives of parents in the School Council and in the Parent Council should hold regular meetings with other parents in order to inform parents in the best way about the progress of meetings and taken decisions. To organize various activities by parents' council that would motivate parents to be active in the school life of their children and closer to the problems that concern them.

- To compile a guide for the work of the Parents Council.

\section{References}

Cicvarić ,J \& Cicvaric R (2009).Vodic kroz savet roditelja. Užice. Užički centar za prava deteta. (Parents guide through the Parent Council. Užice. Center of Užice for the rights of children.) 
Fullan.M(2001)"Kuptimi i ri i ndryshimit në arsim“Tiranë,f.294 (New Understanding of change in education) Glosser,W (2005),Kvalitetna skola-skola bez prisile. Zagreb .Educa (Qualitative school - unenforcemented ]

Instituti Pedagogjik i Kosovës“Kërkime pedagogjike"përmbledhje punimesh ,Prishtinë,2012. (Kosovo Pedagogical Institute "Pedagogical Research" collection of papers, Pristina, 2012)

Kraja,M (2009)"Pedagogjia"Tiranë.Mirgeeralb. (Pedagogy)

Milosevic,N\&Malinic,D(2007). Porodica kao faktor skolskog neuspeha ucenika. (The family as a factor of students failure at school) In:Polovina,N\& Bogunovic,Bed.(2007).Saradnja skole i porodice.(Cooperation of school with parents) Beograd:Institut za Pedagoska Istrazivanja.f.144-155. (Beograd : Institute for pedagogical research)

https://www.google.com/\#q=VODI\%5E+ZA+RAD+VIJE\%5DA+RODITELJA+OSNOVNIH+I+SREDNJIH+\%5BKOLA

https://www.google.com/\#q=savet+roditelja+u+skolama

http://www.masht-gov.net/advCms/?id=119\&lng=Alb\%E2\%80\%8E

http://www.cipcentar.org/i_roditelji_se_pitaju/PDF/SRO/Brosura\%20SR.pdf

http://www.see-educoop.net/aeiq/reports/kosovo_report.pdf

http://www.dils.gov.rs/documents/filesEducation/septembar2012/Participacija\%20roditelja_Jelena\%20Vranjesevic\%20i\%20Zorica\%20Tri kic.pdf

http://www.osbs.edu.ba/dokumenti/skola_roditelji.pdf

http://www.cipcentar.org/i_roditelji_se_pitaju/PDF/clanci/Ukljucivanje\%20roditelja\%20u\%20skole.pdf

http://www.roditelj.org/2013/06/07/vodic-za-roditelje-kroz-skolski-odbor/ 